\title{
PROPERTIES OF ISOLATED LIGNIN FROM MODEL WASTEWATER
}

\author{
Sanita Skudra ${ }^{1}$, Galia Shulga ${ }^{1}$, Vadims Shakels ${ }^{1}$, Lubova Belkova $^{1}$, \\ Skaidrite Reihmane ${ }^{2}$ \\ 1- Latvian State Institute of Wood Chemistry \\ 27 Dzerbenes, LV 1006, Riga, Latvia \\ E-mail: sanita.skudra@gmail.com; shulga@junik.lv; vadim@saint-tech.lv; koks@edi.lv \\ 2- Riga Technical University \\ 14/24 Azenes, LV 1048, Riga, Latvia; e-mail: reihmane@ktf.rtu.lv
}

\begin{abstract}
Model wastewater, imitating the hydrothermal treatment of birch wood in the basins of veneer production, was obtained under laboratory conditions. Birch lignin (BLIG) was isolated from the model wastewater by precipitation with concentarted sulphuric acid. The increase in reduced viscosity with decreasing concentration of BLIG in the water solutions indicated its polyelectrolyte behaviour. The presence of both ionized functional groups and hydrophobic aromatic fragments in the BLIG molecules favoured its surface active properties. With decreasing $\mathrm{pH}$ and increasing concentration, the surface activity of BLIG at the air-water and oil-water interfaces increased, indicating the enhanced hydrophobicity of lignin fragments due to the protonization of its acidic groups. The pronounced surface activity of BLIG was in accordance with the very low value of its critical micelle concentration. The dependence of the emulsion stability on the ionic strength may testify the predominant structural mechanical mechanism of the stabilization of the rapeseed oil-in-water emulsion, containing BLIG as a stabilizer. The revealed surface properties of the isolated lignin allow predicting its application for lowering surface tension in different disperse systems to prevent the coalescence and agglomeration phenomena.
\end{abstract}

Keywords: critical micelle concentration, isolated lignin, model wastewater, polyelectrolyte swelling, veneer production.

\section{Introduction}

Over 50 percent of Latvia is covered by forests and wood represents over 20 percent of Latvia's processing industry. According to forest inventory statistics data, birch is the second largest wood species in Latvia; it contributes to 28.2 percent of total forest area with a total growing stock of 153 million $\mathrm{m}^{3}$. Due to the natural spread of forests to agricultural lands and forest clearings' natural renewing with hardwood species, the proportion of the birch and other hardwood forest stands is increasing. Considering the high proportion of the birch forest stand, its future use is important. One of the most significant birch wood processing ways with a high added value in Latvia is veneer production. Not taking into account the last year's economic situation in the world, the production and demand of veneer is increasing in Latvia and Europe every year [1,2].

The wood hydrothermal treatment process in veneer production generates a great amount of wastewater, replete with low-molecular lignin fragments, hemicelluloses and extractives. These organic substances are responsible for the high chemical oxygen demand and color of wastewater, obtained during wood hydrothermal treatment that, in its turn, has an adverse effect on the environment. Keeping in mind the zero waste policy for rational use of bioresources and the possible usage of waste wood originated matter in practice [3-5], it is very important to extract quantitatively the biomass components from the basin's wastewater and to characterize the isolated ones.

The aim of this work was to investigate the properties of the lignin isolated from laboratory wood hydrolysate, imitating the wastewater of veneer production, targeting to its practical application. 


\section{Materials and methods}

The treatment of birch wood sawdust (cellulose $-40.3 \%$, lignin $-25.2 \%$, extractives $-3.9 \%$ ) was performed in a water solution with $\mathrm{pH} 9.0$ and the hydromodulus 1/50 (sawdust/water) at the temperature $90^{\circ} \mathrm{C}$ for $4 \mathrm{~h}$. The comparison of the elemental and functional compositions of the dry matter derived from the obtained hydrolyzate, imitating the hydrothermal treatment of birch wood in veneer production, and industrial wastewater has shown that their differences in the chemical composition were not significant [6].

Birch lignin (BLIG) was isolated from the obtained wood hydrolysate by using $20 \%$ sulphuric acid solution [7]. Elementary analysis of samples was determined using Elementar Analysensysteme Vario MACRO CHNS. Functional analysis was performed by analytical methods according to [7, 8]. FT-IR spectra were recorded on a spectrophotometer PerkinElmer Spectra One in a range of $450-4000 \mathrm{~cm}^{-1}$, using a $\mathrm{KBr}$ tablets, containing finely ground samples. UV spectra were recorded with a Genesys 10UV spectrophotometer in a range of 220-420 nm. The values of the determined extinction coefficient of BLIG varied from 13.51 $\mathrm{g}^{-1} \mathrm{~cm}^{-1}(\lambda=276 \mathrm{~nm})$ at $\mathrm{pH} 5.3$ to $16.81 \mathrm{~g}^{-1} \mathrm{~cm}^{-1}(\lambda=280 \mathrm{~nm})$ at $\mathrm{pH} 12.7$. These indices were typical for the lignins of hardwood species [9]. The surface tension at the air-water interface was measured by the Wilhelmy plate method, using the tensiometer KRUSS 9K, after $24 \mathrm{~h}$ storage of lignin solutions at room temperature. The viscosity of the diluted solutions was determined in a capillary viscosimeter Schott Ubbelode at a temperature of $25^{\circ} \mathrm{C}$. For surface tension and viscosity determination, a BLIG sample was dissolved in $0.1 \mathrm{M} \mathrm{NaOH}$ in the concentration range $0.0006-0.10 \mathrm{~g} / \mathrm{dl}$. The stabilizing properties of the isolated BLIG were measured by using the emulsion "rapeseed oil-in-water" $(40 / 60, \mathrm{v} / \mathrm{v})$ with a BLIG concentration in the water phase of $0.01-1.0 \mathrm{~g} / \mathrm{dl}$. The $\mathrm{pH}$ values of the water phase, containing BLIG, were adjusted with $1 \mathrm{M} \mathrm{NaOH}$ and $1 \mathrm{M} \mathrm{HCl}$. The emulsions were prepared with a Disperser T10 (IKA, Germany) $(\gamma=9500 \mathrm{rpm})$ for $1 \mathrm{~min}$. The aggregative stability of the emulsions was evaluated by the separation volume of water and separation time. The supramolecular structure of the isolated lignin was examined with a scanning electron microscope (Tesla, Czech Republic).

\section{Results and discussion}

To characterize the lignin low molecular fragments, precipitated from the model wastewater, analytical chemical analysis and Fourier spectroscopy were used. In the FT-IR spectra of BLIG (Fig.1), the typical bands, which are common for hardwood lignins, can be seen. The broad band at $3422 \mathrm{~cm}^{-1}$ was due to the $\mathrm{O}-\mathrm{H}$ bond stretching in phenolic and aliphatic structures, and the minor bands at $2928 \mathrm{~cm}^{-1}$ and $2855 \mathrm{~cm}^{-1}$ were assigned to aliphatic $\mathrm{C}-\mathrm{H}$ stretching in aromatic methoxyl groups, and in methyl and methylene groups of side chains. A band at $1714 \mathrm{~cm}^{-1}$ may be assigned to the presence of unconjugated and conjugated carbonyl and aromatic carboxyl groups in lignin macromolecules. Aromatic skeletal vibrations give three strong peaks at 1606, 1512 and $1419 \mathrm{~cm}^{-1}$. A relative higher intensity of the band at $1606 \mathrm{~cm}^{-1}$, in comparison with the band at $1512 \mathrm{~cm}^{-1}$, may be caused by the presence of a significant amount of syringyl derivatives in the lignin macromolecule and condensed aromatic structures, favouring the increase in the intensity of this absorption band. 


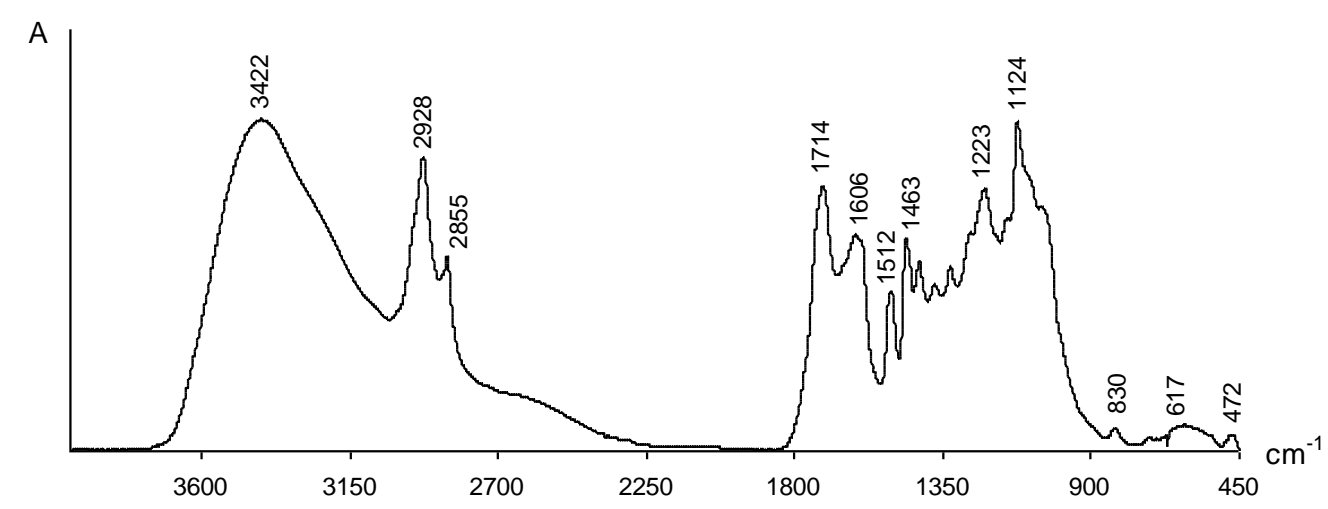

Fig.1. FT-IR spectrum of the isolated birch lignin

A weak band at $1375 \mathrm{~cm}^{-1}$ may be caused by the presence of phenolic $\mathrm{OH}$ and aliphatic $\mathrm{C}-\mathrm{H}$ in methyl groups. The signals at 1327,1124 and $830 \mathrm{~cm}^{-1}$ demonstrate that BLIG contains a certain content of guaiacyl and syringyl units, and the band at $1223 \mathrm{~cm}^{-1}$ represent a phydroxyphenyl unit [10]. A very strong band at $1124 \mathrm{~cm}^{-1}$ may be caused by the $\mathrm{C}-\mathrm{H}$ deformation in the syringyl units as well as in the secondary alcohols or by $\mathrm{C}=\mathrm{O}$ stretching vibrations. The band with a maximum at $1051 \mathrm{~cm}^{-1}$ is complex and may be governed by both the deformation vibrations of $\mathrm{C}-\mathrm{H}$ in the aromatic structures with predominating guaiacyl units, and the deformation vibrations of $\mathrm{C}-\mathrm{O}$ in primary and stretching vibrations of unconjugated $\mathrm{C}=\mathrm{O}$ groups [11].

Table 1.

Elemental and functional composition

\begin{tabular}{|c|c|c|c|c|c|c|c|c|}
\hline Samples & $\begin{array}{c}\mathrm{C} \\
\%\end{array}$ & $\begin{array}{c}\mathrm{H} \\
\%\end{array}$ & $\begin{array}{c}\mathrm{N} \\
\%\end{array}$ & $\begin{array}{c}\mathrm{O} \\
\%\end{array}$ & $\begin{array}{c}\mathrm{S} \\
\%\end{array}$ & $\begin{array}{c}\mathrm{OCH}_{3} \\
\%\end{array}$ & $\begin{array}{c}\mathrm{CO} \\
\%\end{array}$ & $\begin{array}{c}\mathrm{OH} \\
\%\end{array}$ \\
\hline BLIG & 53.36 & 6.63 & 0.61 & 39.03 & 0.37 & 7.53 & 4.76 & 11.24 \\
\hline
\end{tabular}

The content of the main functional groups - methoxyl, carbonyl and hydroxyl groups of BLIG, which were determined by the classical methods of lignin analytical chemistry, is given in Table 1.

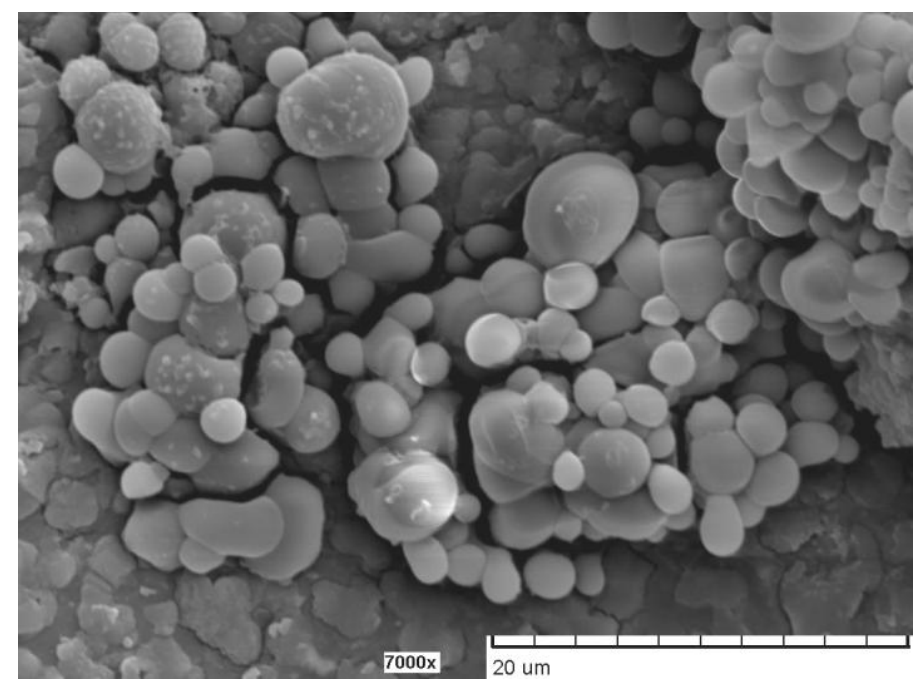

Fig.2. SEM image of the air-dried birch lignin isolated from weak acidic medium 
It has been found [6], that BLIG is rich in a considerable amount of weak phenolic hydroxyl and carboxyl groups, the so-called lignin acidic groups. Their presence is the reason of the polyelectrolyte behaviour of BLIG in aqueous media, which manifests itself in an increase in reduced viscosity with decreasing concentration of lignin in the solution (Fig.3.).

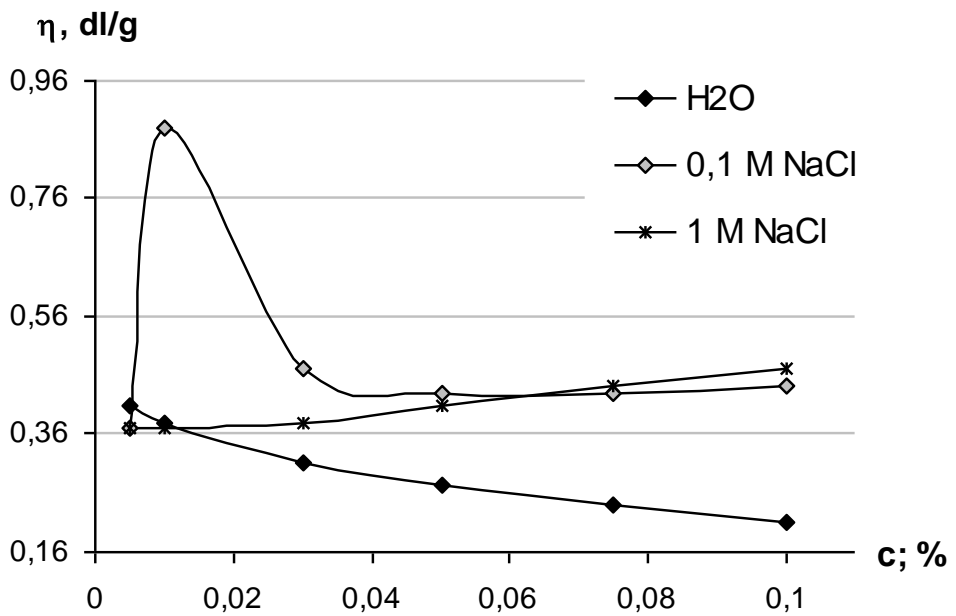

Fig.3. Reduced viscosity of BLIG water solutions vs. their concentration in the presence of $\mathrm{NaCl}$ at $\mathrm{pH} 12.7$

The swelling of lignin macromolecules is expressed, to a greater extent, in strongly alkaline media and in the presence of $0.1 \mathrm{M} \mathrm{NaCl}$. However, the increase in the concentration of $\mathrm{NaCl}$ and decreasing $\mathrm{pH}$ of the BLIG solution favour the inhibition of swelling. The presence of both the ionized functional groups and hydrophobic aromatic fragments in the molecules of the isolated lignin favours its surface active properties. The latter were studied in BLIG water solutions depending on their $\mathrm{pH}$ and concentration values (Fig.4.).

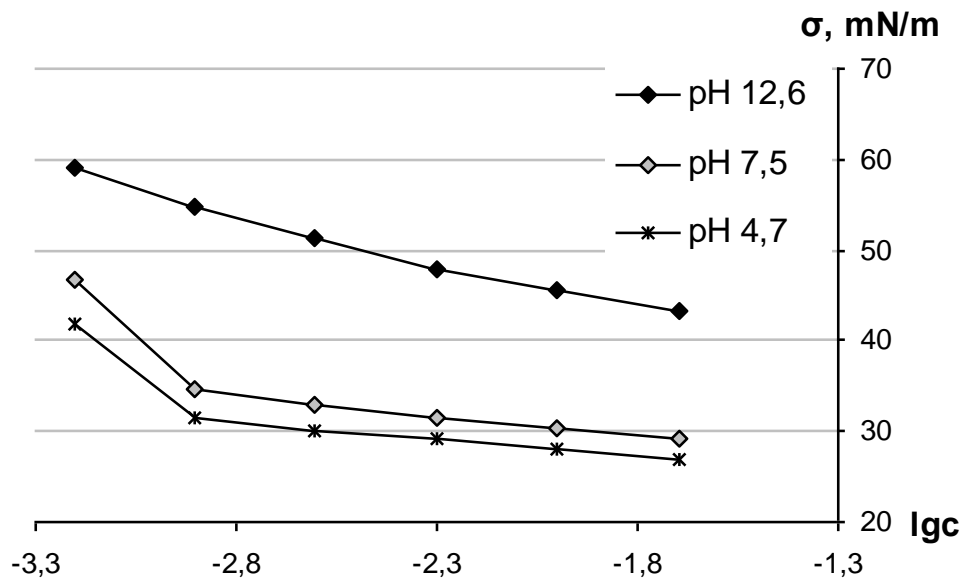

Fig.4. Surface tension at the air-water interface of the BLIG aqueous solutions at
different $\mathrm{pH}$ vs. logarithm of its concentration

With decreasing $\mathrm{pH}$ and increasing concentration, the surface activity of BLIG at the airwater interface grows, indicating the enhanced hydrophobicity of lignin fragments due to the protonization of phenolic and carboxylic groups. In the acid medium, the surface tension of the water solutions at the air-water interface achieves the minimum values, which do not exceed $31.5 \mathrm{mNm}^{-1}$. The pronounced tendency of BLIG molecules to decrease the surface tension at the air-water interface is in accordance with the very low critical micelle 
concentration (CMC) values of BLIG molecules in neutral and acid media that are not higher than $1 \cdot 10^{-3} \mathrm{~g} \mathrm{dl}^{-1}$.

Fig.5. shows the values of the volume of water $(\mathrm{H})$ and the time of separation of the rapeseed oil-in-water emulsion $(\mathrm{t})$, in which the isolated lignin as a stabilizer with different concentrations in the water phase with $\mathrm{pH} 5.5$ was used. According to the obtained results, with increasing content of BLIG in the emulsion, the stability of the emulsion increases, which is indicated by the decrease in the separation volume of water and the increase in the separation time. The presence of $0.1 \mathrm{NaCl}$ in the weak acid water phase decreased still to a greater extent the separation volume of the emulsion, with increasing lignin concentration. At the same time, the presence of $1 \mathrm{M} \mathrm{NaCl}$ in the water phase dramatically impaired the stabilizing action of BLIG and caused the full separation of the emulsion already within the first $10 \mathrm{~min}$ irrespective of the stabilizer concentration.

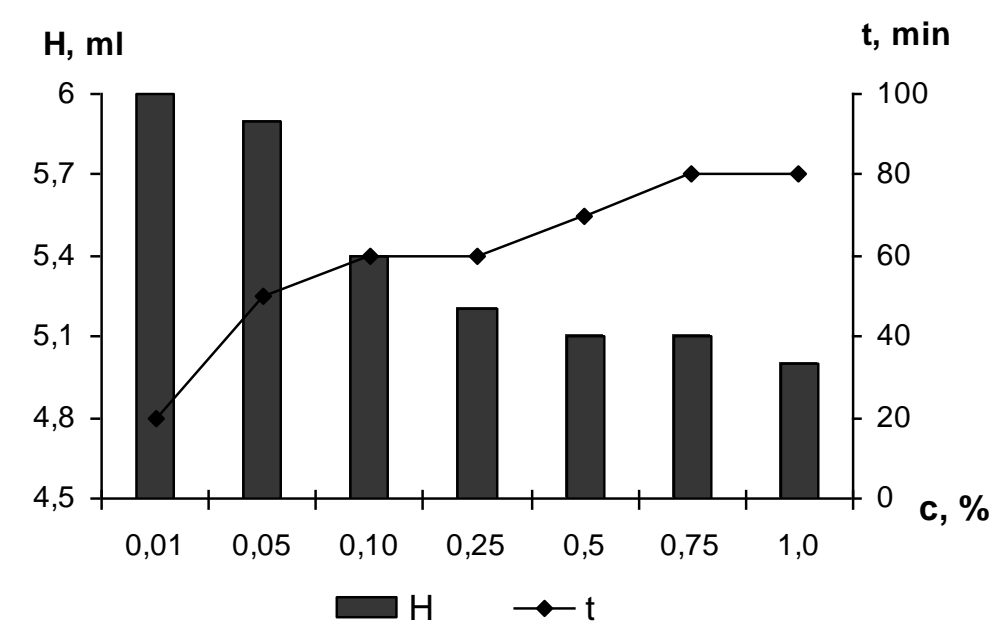

Fig.5. Volumes of water and time of separation of the rapeseed oil-in-water emulsion, containing BLIG of different concentration at $\mathrm{pH} 5.5$

The dependence of the emulsion stability on the ionic strength may confirm the predominant structural mechanical mechanism of the stabilization of the rapeseed oil-in-water emulsion, containing the isolated birch lignin, in the acidic media. This assumption is also confirmed by decreasing stability of the rapeseed oil-in-water emulsion with increasing $\mathrm{pH}$ value of the lignin-containing water phase.

\section{Summary}

In this work, the peculiarities of the chemical composition of birch lignin, isolated from laboratory wood hydrolyzate, imitating the wastewater of veneer production basins, and its surface active properties at air-water and oil-water interfaces depending on the lignin concentration, $\mathrm{pH}$ and ionic strength has been studied. The fine surface-active properties of BLIG allow predicting its usage as a surfactant for lowering surface tension at the interfaces in different disperse systems to prevent their coalescence and agglomeration.

\section{Acknowledgements}

The researches leading to these results have received funding from the Latvian Council of Science for a grant $n^{\circ} 09-1610 \mathrm{c}$, as well as from the funding of the "WOOD-NET" project of FP7/2007-2013 (agreement $n^{\circ} 203459$ ). 


\section{Skudra S., Šuḷa G., Šakels V., Belkova L., Reihmane S. PROPERTIES OF ISOLATED LIGNIN FROM MODEL WASTEWATER}

\section{References}

1. Forest industry in Latvia, wood industry [retrieved on 15.12.2010], website: http://www.latforin.info.

2. Andersons, B., Kokorevics, A. Improving Latvia's wood research capabilities. International Inovations, Issue Food, No. 1, 2011, p. 83-85.

3. Shulga, G., Shakels, V., Brovkina, J., Solodovniks, P., Skudra, S. Synthesis and properties of pHresponsible biodegradable lignin-based surfactants. Abstracts of the 7th World Surfactants Congress 'CESIO 2008', Paris, France, June 22-25, 2008, p. 98.

4. Skudra, S., Šakels, V., Neiberte, B., Šulga, G., Reihmane, S. Physico-chemical characterization of sulphate lignin, obtained from the black liquor of the Kehra Pulp-and-Paper Plant "Horizon" (No Kehras celulozes un papīra rūpnīcas „Horizon” melnā atsārma iegūta sulfātlignīna fizikāli k̦īmiskais raksturojums). Proceedings of RTU, Materials Science and Applied Chemistry, Vol. 1, No. 22, 2010, p. 38-43.

5. Šuļga, G., Brovkina, J., Skudra, S., Šakels, V., Aniskeviča, O. New environmentally friendly lignin binder from hardwood waste, its properties and application for obtaining geocomposites (Jauna videi draudzīga lignīna saistviela no lapu koksnes atlikuma, tās īpašǐbas un pielietojums ǵeokompozītu ieguvei). State Research Programme No. 1-23/65. Substantiation of Deciduous Tree Growing and Rational Use, Novel Products and Technologies (Lapu koku audzēšanas un racionālas izmantošanas pamatojums, jauni produkti un tehnologijas), 2009, p. 150-153.

6. Skudra, S., Shulga, G., Reihmane, S. The study of birch lignin isolated from hydrolyzate imitating wastewater of veneer production. Proceedings of RTU, Material Science and Applied Chemistry, 2011 (submitted for publication).

7. Lin, S.Y., Dence, C. W. (Eds.). Methods in lignin chemistry. Springer-Verlag, Berlin-Heidelberg, 1992, p. 568.

8. Zakis, G.F. Functional analysis of lignins and their derivatives. Tappi Press, Atlanta, 1994.

9. Fengel, D., Wegener, G. Wood - chemistry, ultrastructure, reactions. Walter de Gruyter, Berlin, 1984, p. 613.

10. Sarkanen, K.V., Ludvig, C.H. (Eds.). Lignins: occurrence, formation, structure and reactions. John Wiley \& Sons, New York, 1971.

11. Sun, R. C., Tomkinson, J., Ye, J. Physico-chemical and structural characterization of residual lignins isolated with TAED activated peroxide from ultrasound irradiated and alkali pre-treated wheat straw. Polymer Degradation and Stability, No. 79, 2003, p. 241-251.

Anotācija. Laboratorijas apstākḷos iegūts model̦šks̄īums, kas imitē bērza koksnes apstrādes procesu finiera ražošanas hidrotermiskajos baseinos. No iegūtā modeļšķ̄ìuma izdalīts bērza lignīns (BLIG), nogulsnējot ar sērskābi. Samazinoties BLIG koncentrācijai šķīumāa, tā reducētā viskozitāte palielinās, kas liecina par BLIG polielektrolīto dabu. Jonizēto funkcionālo grupu un hidrofobo aromātisko fragmentu klātbūtne BLIG molekulā nosaka tā virsmas aktīvās ìpašības. Ar šksīduma pH samazināšanos un koncentrācijas palielināšanos BLIG

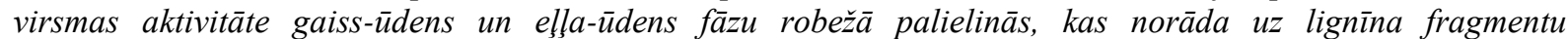
paaugstināto hidrofobitāti, ko izraisa tā skābo grupu protonēšanās. Izteiktā BLIG virsmas aktivitāte ir saskaņā ar tā zemo micellu veidošanās kritisko koncentrāciju. Emulsiju stabilitātes atkarība no jonu spēka var liecināt, ka rapšu ellı-ūdens emulsijā, kas kā stabilizatoru satur BLIG, dominē strukturāli mehāniskais stabilizācijas mehānisms. Izdalītā lignīna atklātās virsmas īpašības rada iespēju to pielietot virsmas spraiguma samazināšanai dažādās dispersās sistēmās, aizkavējot to koalescenci un aglomerāciju. 